\title{
Integrated Inventory Model for Single Vendor Multi-Buyer with a Single Item by Considering Warehouse and Capital Constraint
}

\author{
Agustiandi Agustiandi *, Yoon Mac Kinley Aritonang, Cherish Rikardo \\ Department of Industrial Technology, Parahyangan Catholic University, Bandung, Indonesia \\ Jl. Ciumbuleuit No.94, Hegarmanah, Kec. Cidadap, Kota Bandung, Jawa Barat 40141, Indonesia \\ * Corresponding author: agustiandilin@gmail.com
}

\section{ARTICLE INFO}

Article history

Received December 16, 2020

Revised February 24, 2021

Accepted February 26, 2021

Available Online February 28, 2021

Keywords

Inventory

Capital Constraint

Warehouse Constraint

Lagrange Multipliers

Vendor-buyer

\begin{abstract}
Integrated inventory management coordinates all party's replenishment policies to provide optimal benefits. Many models have been developed, but none of them have considered capital and warehouse constraints comprehensively. It may cause the model which cannot be applied since it has exceeded the capacity. This study developed an integrated inventory model that consisted of one vendor, multi-buyer, and one type of item. The main objective was to minimize the joint total expected cost by considering warehouse, capital, and service level constraint. The optimal formula was constructed by using the Lagrange multipliers method. The results showed that with an increment in holding cost, the vendor tends to reduce lot size to minimize joint total expected cost. It is vice versa to the increment in set up cost. An increment in buyer service level can increase lot size and reduce order frequency. The buyer capacity is essential to determine its capability to apply the optimal replenishment policy.
\end{abstract}

This is an open-access article under the CC-BY-SA license.

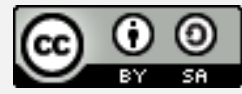

\section{Introduction}

Company competitiveness is determined by its capabilities to satisfy its customer needs and collaborate well with others. Collaboration creates opportunities such as minimize the total cost of the company without sacrifice their customer satisfaction. Customer satisfaction is crucial as it will eventually lead to customer loyalty [1]. This practice can be found in supply chain management, which manages raw materials into finished goods between companies to meet their consumer needs optimally. The supply chain's performance is influenced by the partnership, collaboration, and integration between the company positively [2]. There are many opportunities for collaboration between companies, one of them is inventory management. According to Yang, et al. [3], effective inventory management is fundamental to order fulfillment excellence and supply chain success. Inventory management determines when and the number of goods that will be ordered or produced [4]. Inventory management problems cannot be focused individually in the supply chain because inventory is a part of it [5]. Integrated 
inventory management is essential as individual strategies cannot obtain optimal inventory-saving costs in the entire chain [6].

Integrated inventory management coordinated all party's replenishment policies to provide optimal benefits which were first proved by Goyal [7]. Lee, et al. [8] found that vendor-managed inventory had better performance than retail-managed inventory in general. Aritonang, et al. [9], Huang [10], Hsu and Lee [11], Jha and Shanker [6], Kurdhi, et al. [12], Mou, et al. [13], and Vijayashree and Uthayakumar [14] developed an integrated inventory model with crashing lead time to minimize the total cost of inventory. AlDurgam, et al. [15], Hoque and Bhattacharya [16], Liao, et al. [17], Ouyang, et al. [18], Tarhini, et al. [19], Utama [20] considered warehouse capacity as a constraint in the developed model to ensure that replenishment policy did not exceed it. On the other side, other researchers observed capital capacity as a constraint in the model [3], [21], [22]. Some researchers explained another possibility that might work in an integrated inventory system such as sustainability aspect [23], [24], contract policy [25], [26], [27], [28]. Some models were developed specifically for a certain number (single or multi) of vendor, buyer, and item case. This research, however, focused on single-vendor multi-buyer with a single item case. Usually, it can be found in companies that monopolize related sales of certain goods, such as franchise businesses and others.

In inventory management, capital capacity determines a company's ability to produce or buy many goods [5]. On the other hand, warehouse capacity determines the company's ability to store many goods produced or bought [5]. However, previous research has not considered capital and warehouse constraints comprehensively. It may cause the optimal decision in the model cannot be applied as it has exceeded the capacity. Thus, this research aimed to develop an integrated inventory model by considering capital and warehouse constraints comprehensively to overcome previous research weaknesses. Furthermore, the sensitivity analysis results can help practitioners understand what factor might affect their decision to create a proper plan accordingly.

This paper's organization is presented as follows: Section 2 describes assumptions and notations, mathematical models, algorithm proposals, data collection, and experimental procedures. Section 3 presents the solution of optimization and sensitivity analysis. Section 4 outlines the conclusions and suggestions for further research.

\section{Methods}

\subsection{Assumptions and Notations}

There are several assumptions used in this study as follows:

1. Demand among buyers is independent and stochastic.

2. There is no fluctuation in costs.

3. Each buyer checks the availability of goods using a continuous review system. So when the number of available goods reaches the reorder point, the buyer will place an order.

4. If a shortage occurs, the buyer will backorder to cover it. The vendor never experiences shortages as the vendor can provide sufficient quantities of goods to meet buyer demand.

5. The vendor never experiences problems with warehouse and capital capacity.

6. Transportation costs per unit from a vendor to the buyer are constant and independent of the number of orders.

7. Delivery lead time between vendor to buyers is constant. 
The notation used in the developed model can be seen as follows.

$\mathrm{N}$ : The number of buyers

for the buyer to "i" $(\mathrm{i}=1,2, \ldots, \mathrm{N})$

$\mathrm{D}_{\mathrm{i}} \quad$ : Average demand per unit time

$\mathrm{D} \quad$ : Total average demand per unit time $\left(\mathrm{D}=\sum_{\mathrm{i}=1}^{\mathrm{N}} \mathrm{D}_{\mathrm{i}}\right)$

$\mathrm{A}_{\mathrm{bi}} \quad$ : Ordering cost per order

$\mathrm{C}_{\mathrm{bi}} \quad$ : Unit purchase cost

$\mathrm{h}_{\mathrm{bi}}$ : Holding cost rate (per monetary unit invested in inventory) per unit time

$\mathrm{Q}_{\mathrm{i}} \quad$ : Order quantity (decision variable)

$\mathrm{k}_{\mathrm{i}} \quad$ : safety factor $\rightarrow$ Can be find by using the $\mathrm{Z}$ table

$\mathrm{L}_{\mathrm{i}} \quad$ : Lead time

$a_{i} \quad$ : The proportion of demands that are not met from stock, so $\left(1-\alpha_{i}\right)$ is the service level

$\sigma_{\mathrm{i}} \quad:$ Standard deviation

$\phi\left(\mathrm{k}_{\mathrm{i}}\right) \quad$ : Standard normal probability density function

$\Phi\left(\mathrm{k}_{\mathrm{i}}\right)$ : The standard normal cumulative distribution function

$\mathrm{W}_{\mathrm{i}}$ : Warehouse capacity

$\mathrm{w} \quad$ : Storage requirement for one unit

$\mathrm{J}_{\mathrm{i}} \quad$ : Capital capacity

$\lambda_{\mathrm{bi}} \quad$ : Lambda in Lagrange function for warehouse capacity constraint

$\lambda_{\mathrm{ci}} \quad$ : Lambda in Lagrange function for capital capacity constraint for vendors

$\mathrm{P} \quad$ : production rate, $\mathrm{P}>\mathrm{D}$

$\mathrm{A}_{\mathrm{v}} \quad$ : Setup cost per setup

$\mathrm{C}_{\mathrm{v}} \quad$ : Unit production costs $\left(\mathrm{C}_{\mathrm{v}}<\mathrm{C}_{\mathrm{bi}}, \nabla_{\mathrm{i}}\right)$

$\mathrm{h}_{\mathrm{v}}$ : Holding cost rate (per monetary unit invested in inventory) per unit time

$\mathrm{m} \quad$ : Number of lots delivered from the vendor to each buyer in a production cycle (same for all the buyers), a positive integer (decision variable)

Q : Lot size in each delivery to meet the demand of all buyers, $\mathrm{Q}=\sum_{\mathrm{i}=\mathrm{i}}^{\mathrm{N}} \mathrm{Q}_{\mathrm{i}}$ (decision variable)

\subsection{Mathematical Formulation}

The developed model is modified from the integrated inventory model by Jha and Shanker [6] with additional warehouse and capital constraints from Tersine [5]. The mathematical formulation of the developed model is as follows.

$\operatorname{Min} J T E C_{(\mathrm{Q}, \mathrm{m})}=\frac{\mathrm{D}}{\mathrm{Q}}\left(\frac{\mathrm{A}_{\mathrm{v}}}{\mathrm{m}}+\sum_{\mathrm{i}=1}^{\mathrm{N}} \mathrm{A}_{\mathrm{bi}}\right)+\sum_{\mathrm{i}=1}^{\mathrm{N}}\left(\mathrm{h}_{\mathrm{bi}} \mathrm{C}_{\mathrm{bi}}\left(\frac{\mathrm{Q}}{2 \mathrm{D}} \mathrm{D}_{\mathrm{i}}+\mathrm{k}_{\mathrm{i}} \mathrm{\sigma}_{\mathrm{i}} \sqrt{\mathrm{L}_{\mathrm{i}}}\right)\right)+\frac{\mathrm{Q}}{2} \mathrm{~h}_{\mathrm{v}} \mathrm{C}_{\mathrm{v}}\left(\mathrm{m}\left(1-\frac{\mathrm{D}}{\mathrm{P}}\right)-1+\frac{2 \mathrm{D}}{\mathrm{P}}\right)$

$$
\begin{aligned}
& \begin{array}{ll}
\text { Subject } & \mathrm{D} \sigma_{\mathrm{i}} \sqrt{\mathrm{L}_{\mathrm{i}}} \Psi\left(\mathrm{k}_{\mathrm{i}}\right) \\
\text { to } & \mathrm{D}_{\mathrm{i}} \mathrm{Q}
\end{array} \\
& \text { with } \Psi\left(k_{\mathrm{i}}\right)=\phi\left(\mathrm{k}_{\mathrm{i}}\right)-\mathrm{k}_{\mathrm{i}}\left(1-\Phi\left(\mathrm{k}_{\mathrm{i}}\right)\right) \\
& \text { w } \mathrm{D}_{\mathrm{i}} \frac{\mathrm{Q}}{\mathrm{D}} \leq \mathrm{W}_{\mathrm{i}} \\
& \frac{\mathrm{C}_{\mathrm{bi}} \mathrm{D}_{\mathrm{i}} \mathrm{Q}}{2 \mathrm{D}} \leq \mathrm{J}_{\mathrm{i}}
\end{aligned}
$$


The objective function (1) is to minimize the Joint Total Expected Cost (JTEC) of buyer and vendor inventory costs which consist of holding cost, set up cost, and order cost. Service level constraint (2) ensures that the buyer's service level is satisfied. Warehouse (3) and capital (4) constraints are added to ensure that the decision variable's optimal value does not exceed the buyer capacity. To find the $\mathrm{Q}$ and $\mathrm{m}$ formula's optimal value, the objective function (1) needs to be modified with the Lagrange method and derived in Eq. 5.

$$
\begin{aligned}
\mathrm{L}_{\left(\mathrm{Q}, \mathrm{m}, \lambda_{\mathrm{bi}}, \lambda_{\mathrm{ci}}\right)}= & \frac{\mathrm{D}}{\mathrm{Q}}\left(\frac{\mathrm{A}_{\mathrm{v}}}{\mathrm{m}}+\sum_{\mathrm{i}=1}^{\mathrm{N}} \mathrm{A}_{\mathrm{bi}}\right)+\sum_{\mathrm{i}=1}^{\mathrm{N}}\left(\mathrm{h}_{\mathrm{bi}} \mathrm{C}_{\mathrm{bi}}\left(\frac{\mathrm{Q}}{2 \mathrm{D}} \mathrm{D}_{\mathrm{i}}+\mathrm{k}_{\mathrm{i}} \mathrm{O}_{\mathrm{i}} \sqrt{\mathrm{L}_{\mathrm{i}}}\right)\right)+\frac{\mathrm{Q}}{2} \mathrm{~h}_{\mathrm{v}} \mathrm{C}_{\mathrm{v}}\left(\mathrm{m}\left(1-\frac{\mathrm{D}}{\mathrm{P}}\right)-1+\frac{2 \mathrm{D}}{\mathrm{P}}\right) \\
& +\sum_{i=1}^{N}\left(\lambda_{b i}\left(\mathrm{w} \mathrm{D}_{\mathrm{i}} \frac{\mathrm{Q}}{\mathrm{D}}-\mathrm{W}_{\mathrm{i}}\right)+\sum_{i=1}^{N}\left(\lambda_{c i}\left(\frac{\mathrm{C}_{\mathrm{bi}} \mathrm{D}_{\mathrm{i}} \mathrm{Q}}{2 \mathrm{D}}-\mathrm{J}_{\mathrm{i}}\right)\right)\right.
\end{aligned}
$$

$\mathrm{Q}$ optimal formula divided into two, which are $\mathrm{Q}$ without constraint formula was found by deriving objective function (1) to the value of $Q$, which can be seen in Eq. 6.

$Q_{\text {optimal }}=\sqrt{\frac{2 \mathrm{D}\left(\frac{\mathrm{A}_{\mathrm{v}}}{\mathrm{m}}+\left(\sum_{\mathrm{i}=1}^{\mathrm{N}} \mathrm{A}_{\mathrm{bi}}\right)\right)}{\left(\sum_{\mathrm{i}=1}^{\mathrm{N}} \frac{\mathrm{h}_{\mathrm{bi}} \mathrm{C}_{\mathrm{bi}} \mathrm{D}_{\mathrm{i}}}{\mathrm{D}}+\mathrm{h}_{\mathrm{v}} \cdot \mathrm{C}_{\mathrm{v}} \cdot\left(\mathrm{m}\left(1-\frac{\mathrm{D}}{\mathrm{P}}\right)-1+\frac{2 \mathrm{D}}{\mathrm{P}}\right)\right.}}$

$\mathrm{Q}$ with constraint formula, which is found by deriving objective function (5) to the value of Q, can be seen in Eq. 7.

$\mathrm{Q}_{\text {optimal }}=\sqrt{\frac{2 \mathrm{D}\left(\frac{\mathrm{A}_{\mathrm{v}}}{\mathrm{m}}+\left(\sum_{\mathrm{i}=1}^{\mathrm{N}} \mathrm{A}_{\mathrm{bi}}\right)\right)}{\left(\sum_{\mathrm{i}=1}^{\mathrm{N}} \frac{\mathrm{h}_{\mathrm{bi}} \mathrm{C}_{\mathrm{bi}} \mathrm{D}_{\mathrm{i}}}{\mathrm{D}}+\mathrm{h}_{\mathrm{v}} \mathrm{C}_{\mathrm{v}}\left(\mathrm{m}\left(1-\frac{\mathrm{D}}{\mathrm{P}}\right)-1+\frac{2 \mathrm{D}}{\mathrm{P}}\right)+\left(\sum_{\mathrm{i}=1}^{\mathrm{N}} \frac{\lambda_{\mathrm{bi}} \mathrm{wD}_{\mathrm{i}}}{\mathrm{D}}\right)+\left(\sum_{\mathrm{i}=1}^{\mathrm{N}} \frac{\lambda_{\mathrm{ci}} \mathrm{C}_{\mathrm{bi}} \mathrm{D}_{\mathrm{i}}}{2 \mathrm{D}}\right)\right.}}$

Buyer "i" orders a number of " $Q_{i}$ " goods and the vendor produces a number of $\mathrm{mQ}$ goods with a production level of $\mathrm{P}$ in one set up. Goods are sent in the amount of $\mathrm{Q}$ and $\mathrm{m}$ times to meet the demands of all buyers. For this reason, the buyer's order quantity can be calculated by using Eq. 8

$\mathrm{Q}_{\mathrm{i}}=\frac{\mathrm{D}_{\mathrm{i}}}{\mathrm{D}} \mathrm{Q}$

$\mathrm{m}$ is an optimal formula, which was found by deriving objective function (1) to the value of $\mathrm{m}$, which can be seen in Eq. 9.

$\mathrm{m}_{\text {optimal }}=\sqrt{\frac{2 \mathrm{DA}_{\mathrm{v}}}{\mathrm{Q}^{2} \mathrm{~h}_{\mathrm{v}} \mathrm{C}_{\mathrm{v}}\left(1-\frac{\mathrm{D}}{\mathrm{P}}\right)}}$ 
Optimal value of $\lambda_{\mathrm{bi}}$ can be calculated by using the following formula [5].

$\lambda_{\mathrm{bi}}\left(\frac{\mathrm{wD}_{\mathrm{i}} \mathrm{Q}}{\mathrm{D}}-\mathrm{W}_{\mathrm{i}}\right)=0$

$\lambda_{\text {ci }}\left(\frac{C_{b i} D_{i} Q}{2 D}-J_{i}\right)=0$

The hessian matrix in Eq. 12 is used to know whether the calculated value of $\mathrm{Q}$ and $\mathrm{m}$ are local minimum points or not.

$\mathrm{H}_{(\mathrm{Q}, \mathrm{m})}=\left[\begin{array}{lc}\frac{\partial^{2} \mathrm{JTEC}(\mathrm{Q}, \mathrm{m})}{\partial^{2} \mathrm{Q}} & \frac{\partial^{2} \operatorname{JTEC}(\mathrm{Q}, \mathrm{m})}{\partial \mathrm{Q} \partial \mathrm{m}} \\ \frac{\partial^{2} \operatorname{JTEC}(\mathrm{Q}, \mathrm{m})}{\partial \mathrm{m} \partial \mathrm{Q}} & \frac{\partial^{2} \mathrm{JTEC}(\mathrm{Q}, \mathrm{m})}{\partial^{2} \mathrm{~m}}\end{array}\right]=\left[\begin{array}{cc}\frac{2 \mathrm{D}\left(\frac{\mathrm{A}_{\mathrm{v}}}{\mathrm{m}}+\left(\sum_{\mathrm{i}=1}^{\mathrm{N}} \mathrm{A}_{\mathrm{bi}}\right)\right)}{\mathrm{Q}^{3}} & \frac{\mathrm{DA}_{\mathrm{v}}}{\mathrm{m}^{2} \mathrm{Q}^{2}}+\frac{\mathrm{h}_{\mathrm{v}} \mathrm{C}_{\mathrm{v}}\left(1-\frac{\mathrm{D}}{\mathrm{P}}\right)}{2} \\ \frac{\mathrm{DA}_{\mathrm{v}}+\frac{\mathrm{h}_{\mathrm{v}} \mathrm{C}_{\mathrm{v}}\left(1-\frac{\mathrm{D}}{\mathrm{P}}\right)}{2}}{\frac{\mathrm{m}^{2} \mathrm{Q}^{2}}{2}} & \frac{2 \mathrm{~A}_{\mathrm{v}} \mathrm{D}}{\mathrm{m}^{3} \mathrm{Q}}\end{array}\right]$

To minimize the JTEC (1), all of the leading principal minor from the Hessian matrix must be positive so that values of $\mathrm{Q}$ and $\mathrm{m}$ are local minimum [29].

The first leading principal minor is seen in equation (13)

$\frac{2 \mathrm{D}\left(\frac{\mathrm{A}_{\mathrm{v}}}{\mathrm{m}}+\left(\sum_{\mathrm{i}=1}^{\mathrm{N}} \mathrm{A}_{\mathrm{bi}}\right)\right)}{\mathrm{Q}^{3}}$

In Eq. 13, due to each variable's positive value and parameter, the first leading principal minor is also positive. Thus, it can be concluded that the local minimum requirement for the first leading principal minor has been satisfied.

The second leading principal minor can be seen in equation (14).

$\frac{4 \mathrm{D}^{2}\left(\frac{\mathrm{A}_{\mathrm{v}}}{\mathrm{m}}+\left(\sum_{\mathrm{i}=1}^{\mathrm{N}} \mathrm{A}_{\mathrm{bi}}\right)\right) \mathrm{A}_{\mathrm{v}}}{\mathrm{Q}^{4} \mathrm{~m}^{3}}-\left(\frac{\mathrm{DA}_{\mathrm{v}}}{\mathrm{m}^{2} \mathrm{Q}^{2}}+\frac{\mathrm{h}_{\mathrm{v}} \mathrm{C}_{\mathrm{v}}\left(1-\frac{\mathrm{D}}{\mathrm{P}}\right)}{2}\right)^{2}$ 


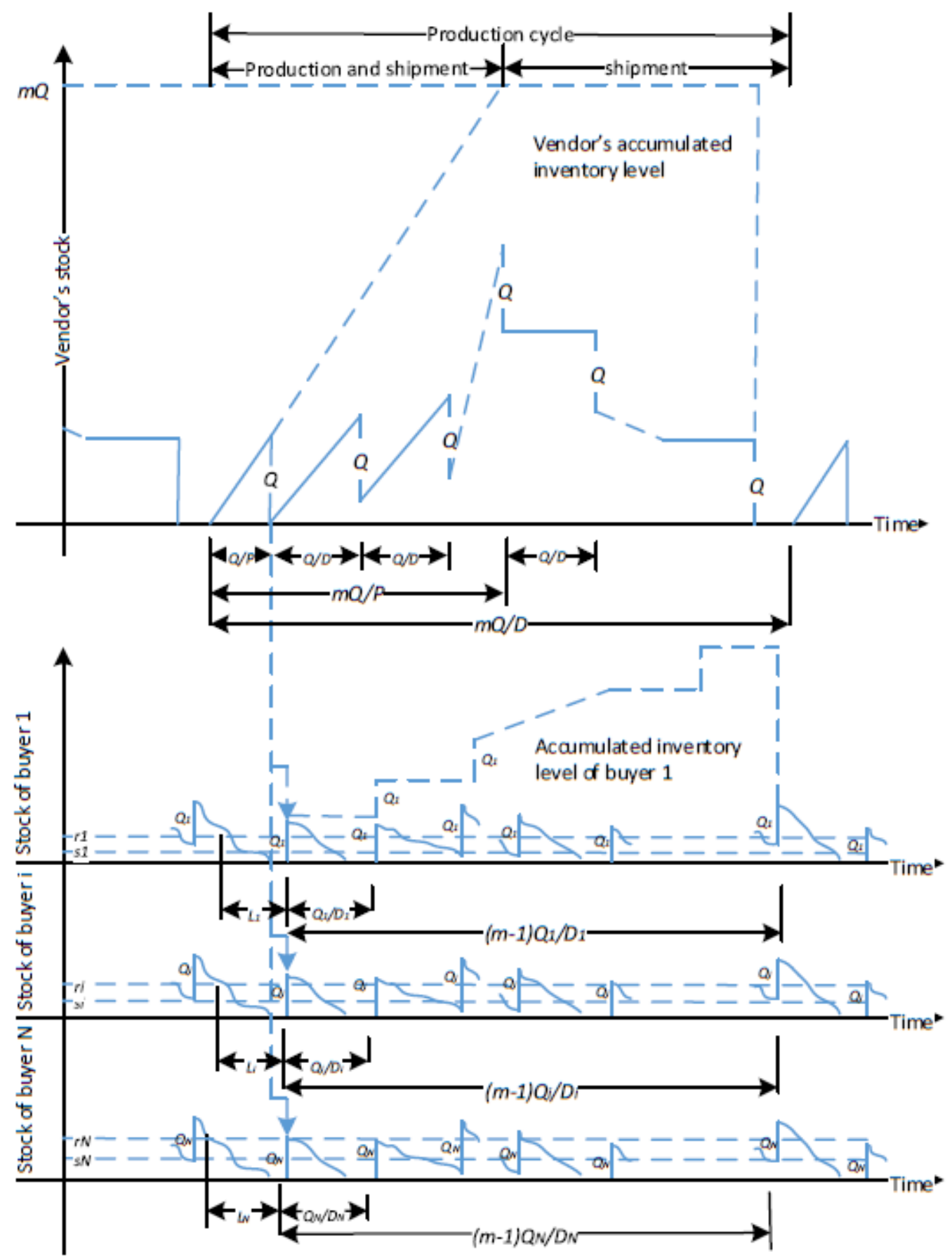

Fig. 1. Inventory system integrated single-vendor multi-buyer with a single item [6]

The second leading principal minor's value is difficult to prove due to the lack of information related to the value of variables and parameters. Thus, further calculations are needed for Eq. 14 to know whether the local minimum requirement is satisfied or not for the second leading principal minor.

In Fig. 1, the delivery system applied is based on the second model of [30]. Some batches of goods will be sent by the vendor to the buyer when the buyer's batches from the previous period have reached to the reorder point. Shipment is done simultaneously 
to meet the average demand from all buyers. Although it was done simultaneously, each buyer may obtain the shipped item depending on the lead time.

The vendor cycles consist of production and shipment cycles as well as shipping cycles. In the production and shipment cycle, the vendor produces goods, and some of the goods will be ship to the buyer. The remaining production goods will be stored and shipped in the shipping cycle.

\subsection{Algorithm}

This section consists of steps to solve the single-vendor multi-buyer and single item integrated inventory problem. The algorithm steps can be seen in Fig. 2.

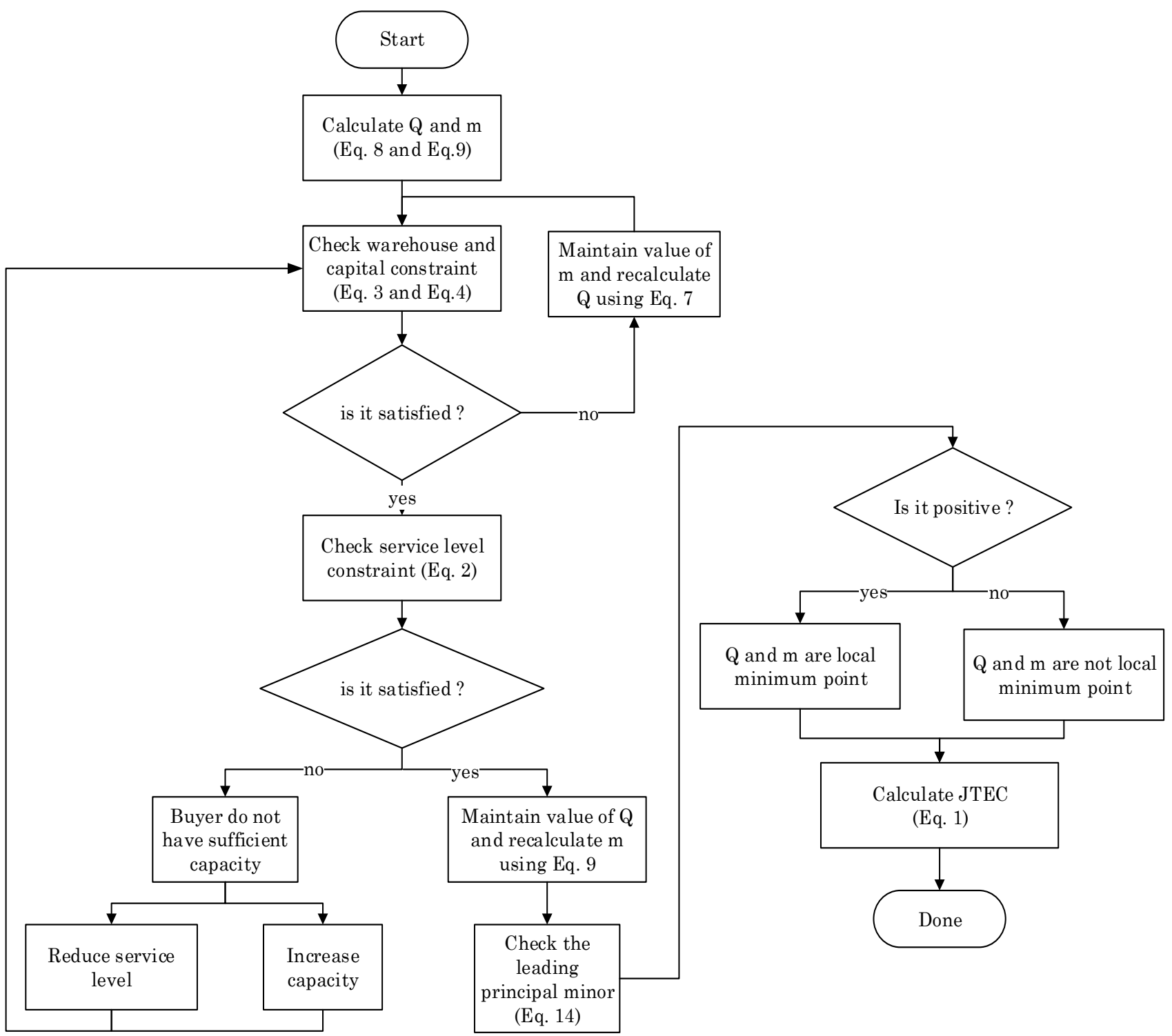

Fig. 2. Algorithm Flowchart 
Procedure details are presented as follows:

1) Calculate the optimal value of $\mathrm{Q}$ and $\mathrm{m}$ by using Eq. 6 and Eq. 9. First, set the value of $m$ equal to 1 and find the value of $Q$ by using Eq. 6. The calculated value of $\mathrm{Q}$ is used to find the value of $\mathrm{m}$ by using Eq. 9. The iteration is done continuously until the value of $\mathrm{Q}$ and $\mathrm{m}$ are the same as the previous one.

2) Check the existing constraints by using Eq. 3 and Eq. 4. Suppose the buyer warehouse and capital constraints have been satisfied. In that case, the next step is to check the service level constraints by using Eq. 2. If all of the constraints are satisfied, then the value of $\mathrm{Q}$ and $\mathrm{m}$ obtained is optimal and feasible. Continue to Step 3 if the existing constraints are not satisfied.

3) Calculate the new value of $Q$ and $m$. First, use the calculated value of $m$ from step 1 and find the optimal values $\lambda_{\mathrm{bi}}$ and $\lambda_{\text {ci }}$ by using Eq. 10 and Eq. 11 simultaneously. The calculation is done by determining the $\lambda$ value on an individual basis in advance with other $\lambda$ values is set to a constant value. After that, recalculate $\mathrm{Q}$ by using Eq. 7 and go back to step 2. If the constraints still cannot be satisfied, it can be concluded that the buyer capacity is not sufficient to satisfy the determined service level. Therefore, the buyer needs to increase their own capacity or lower their determined service level. After that, go to step 1 and recalculate the optimal value of $\mathrm{Q}$ and $\mathrm{m}$. If the constraints are satisfied, then use the new value of $Q$ to calculate the new value of $m$ by using Eq. 9. The value of $Q$ and $\mathrm{m}$ needs to be rounded up or down to become an integer value. Select the rounded value combination based on the most minimum joint total expected cost and not violate the existing constraints.

4) Check the second leading principal minor to know whether the calculated value of $\mathrm{Q}$ and $\mathrm{m}$ are local minimum or not by using Eq. 14. If the value is positive, then the values of $\mathrm{Q}$ and $\mathrm{m}$ are a local minimum. The value of $\mathrm{Q}$ and $\mathrm{m}$ can still be used regardless it is a local minimum or not because all of the existing constraints had been satisfied. The joint total expected cost can be calculated by using Eq. 1.

\subsection{Data Collection}

Hypothetical data are used in the calculation, which can be seen in

Table 1. The data are referred to as Jha and Shanker [6] cases with additional data such as buyer capital capacity, buyer warehouse capacity.

\subsection{Experimental Procedures}

The integrated inventory for single-vendor multi-buyer with a single item case is modeled in section 2.2. The developed model was used to solve the mathematical problem using an algorithm explained in section 2.3. The calculation was done manually by using excel software. Sensitivity analysis between decision variables was conducted by modifying one decision variable value and recalculating another one's optimal value. On the other hand, certain parameter values were modified, and optimal decision variables were recalculated. Sensitivity analysis is used to test the relationship between the value $\mathrm{Q}$ and $\mathrm{m}$, the changes in the value of vendor holding cost to $\mathrm{Q}$ and $\mathrm{m}$, and the effect of service level on the value of $\mathrm{Q}$ and $\mathrm{m}$. 
Table 1. Hypothetical Data of Buyers and Vendors

\begin{tabular}{|c|c|c|c|c|c|c|c|c|c|c|}
\hline \multicolumn{11}{|c|}{ Hypothetical Data of Buyer } \\
\hline \multirow{2}{*}{ Buyer } & Demand & order cost & $\begin{array}{c}\text { unit } \\
\text { purchase } \\
\text { cost }\end{array}$ & $\begin{array}{l}\text { holding } \\
\text { cost } \\
\text { rate }\end{array}$ & $\begin{array}{l}\text { standard } \\
\text { deviation }\end{array}$ & $\begin{array}{l}\text { lead } \\
\text { time }\end{array}$ & $\begin{array}{c}\text { Warehouse } \\
\text { capacity }\end{array}$ & $\begin{array}{l}\text { volume } \\
\text { goods }\end{array}$ & capital & $\begin{array}{c}\text { service } \\
\text { level }\end{array}$ \\
\hline & $\begin{array}{c}\mathrm{D}_{\mathrm{i}} \\
\text { (Units / } \\
\text { year) }\end{array}$ & $\begin{array}{c}\mathrm{A}_{\mathrm{bi}} \\
(\$ / \\
\text { order) }\end{array}$ & $\begin{array}{c}\mathrm{C}_{\mathrm{bi}} \\
(\$ / \text { Unit })\end{array}$ & $\mathrm{h}_{\mathrm{bi}}$ & $\sigma_{\mathrm{i}}$ & $\begin{array}{c}\mathrm{L}_{\mathrm{i}} \\
\text { (day) }\end{array}$ & $\mathrm{W}_{\mathrm{i}}\left(\mathrm{m}^{3}\right)$ & $\begin{array}{l}\mathrm{w}\left(\mathrm{m}^{3} /\right. \\
\text { unit) }\end{array}$ & $\mathrm{J}_{\mathrm{i}}(\$)$ & $\begin{array}{c}1-a_{i} \\
(\%)\end{array}$ \\
\hline 1 & 1,000 & 3,000 & 250 & 0.2 & 20 & 3 & 2,000 & 10 & 31,000 & $80 \%$ \\
\hline 2 & 5,000 & 4,000 & 200 & 0.2 & 50 & 2 & 10,000 & 10 & 129,000 & $95 \%$ \\
\hline 3 & 800 & 3,500 & 220 & 0.2 & 25 & 4 & 1,500 & 10 & 11,500 & $80 \%$ \\
\hline \multicolumn{11}{|c|}{ Hypothetical Data of Vendor } \\
\hline \multicolumn{3}{|c|}{ Parameter } & \multicolumn{6}{|c|}{ Information } & \multicolumn{2}{|c|}{ value } \\
\hline \multicolumn{3}{|c|}{$\mathrm{P}$} & \multicolumn{6}{|c|}{ Production capacity (units / year) } & \multicolumn{2}{|c|}{7,000} \\
\hline \multicolumn{3}{|c|}{$\mathrm{A}_{\mathrm{v}}$} & \multicolumn{6}{|c|}{ Setup cost $(\$)$} & \multicolumn{2}{|c|}{4,000} \\
\hline \multicolumn{3}{|c|}{$\mathrm{H}_{\mathrm{v}}$} & \multicolumn{6}{|c|}{ Holding cost rate } & \multicolumn{2}{|c|}{0.2} \\
\hline \multicolumn{3}{|c|}{$\mathrm{C}_{\mathrm{v}}$} & \multicolumn{6}{|c|}{ Unit production cost ( $\$$ / unit) } & \multicolumn{2}{|c|}{150} \\
\hline
\end{tabular}

\section{Results and Discussion}

\subsection{Solution Optimization}

The optimal solution in the mathematical calculation using the developed model can be seen in

Table 2.

Table 2. Optimal Solution

$\mathrm{Q}=888$ units, $\mathrm{m}=9$ times

Buyer

1

2

3
$\mathbf{Q}_{\mathbf{i}}$

Order Quantity (Units)

131

653

104

To minimize the joint total expected cost, each buyer's order quantity decision can be made according to the result in

Table 2. So, buyer 1 needed to order for 131 units, buyer 2 needed to order for 653 units, and buyer 3 had to order for 104 units. The vendor production unit was calculated by multiplication of the value of $\mathrm{Q}$ (888 units) and $\mathrm{m}$ (9 times), which was 7,992 units. The joint total expected cost was $\$ 148,844,444.444$.

\subsection{Sensitivity Analysis}

This section consisted of sensitivity analysis of parameters and the value of decision variables. The decision variables were $\mathrm{Q}$ (lot size of goods) and $\mathrm{m}$ (number of shipments). The sensitivity analysis was conducted by using the calculation of hypothetical data. 


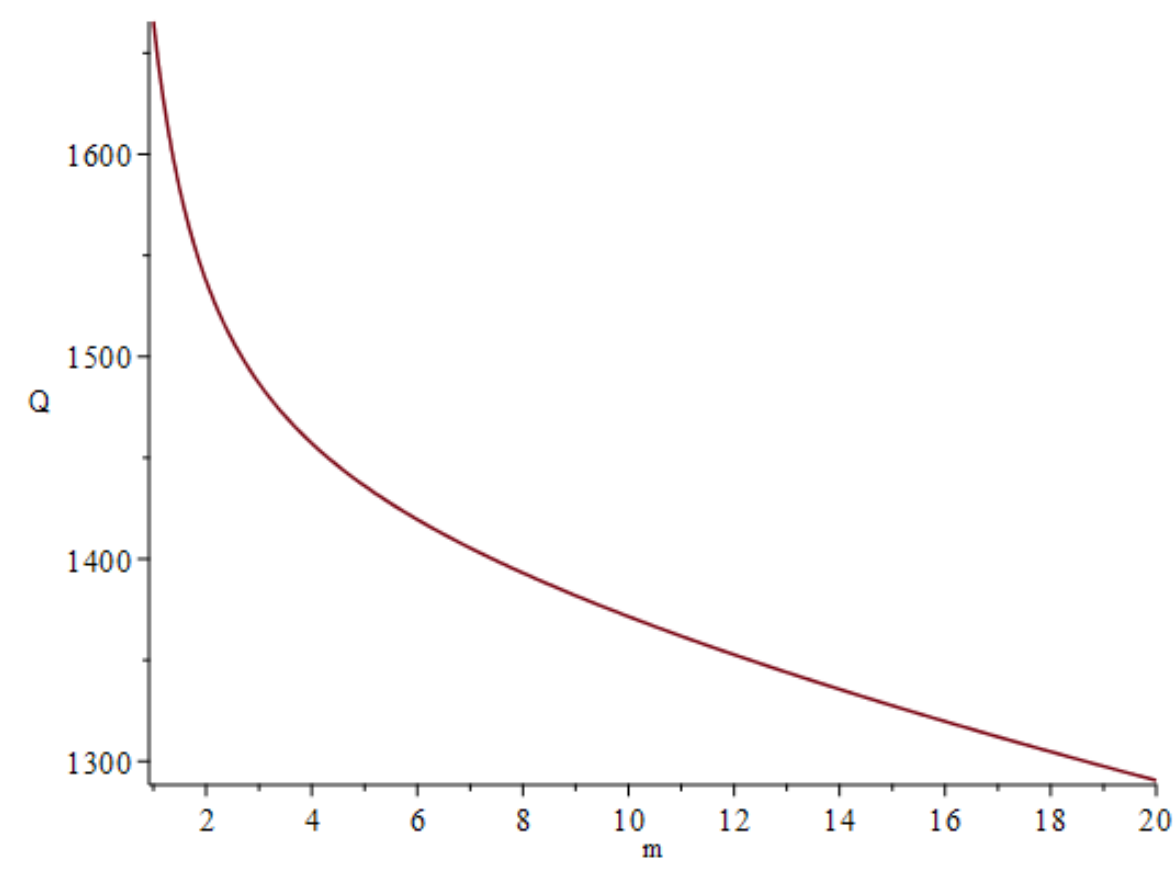

Fig. 3. The relationship between the $\mathrm{Q}$ and $\mathrm{m}$ values

Fig. 3 exploited that $\mathrm{Q}$ and $\mathrm{m}$ had negative correlations in minimizing the joint total expected cost. An increment in the value of $m$ would certainly decrease the value of $\mathrm{Q}$, that was to minimize the joint total expected cost and vice versa.

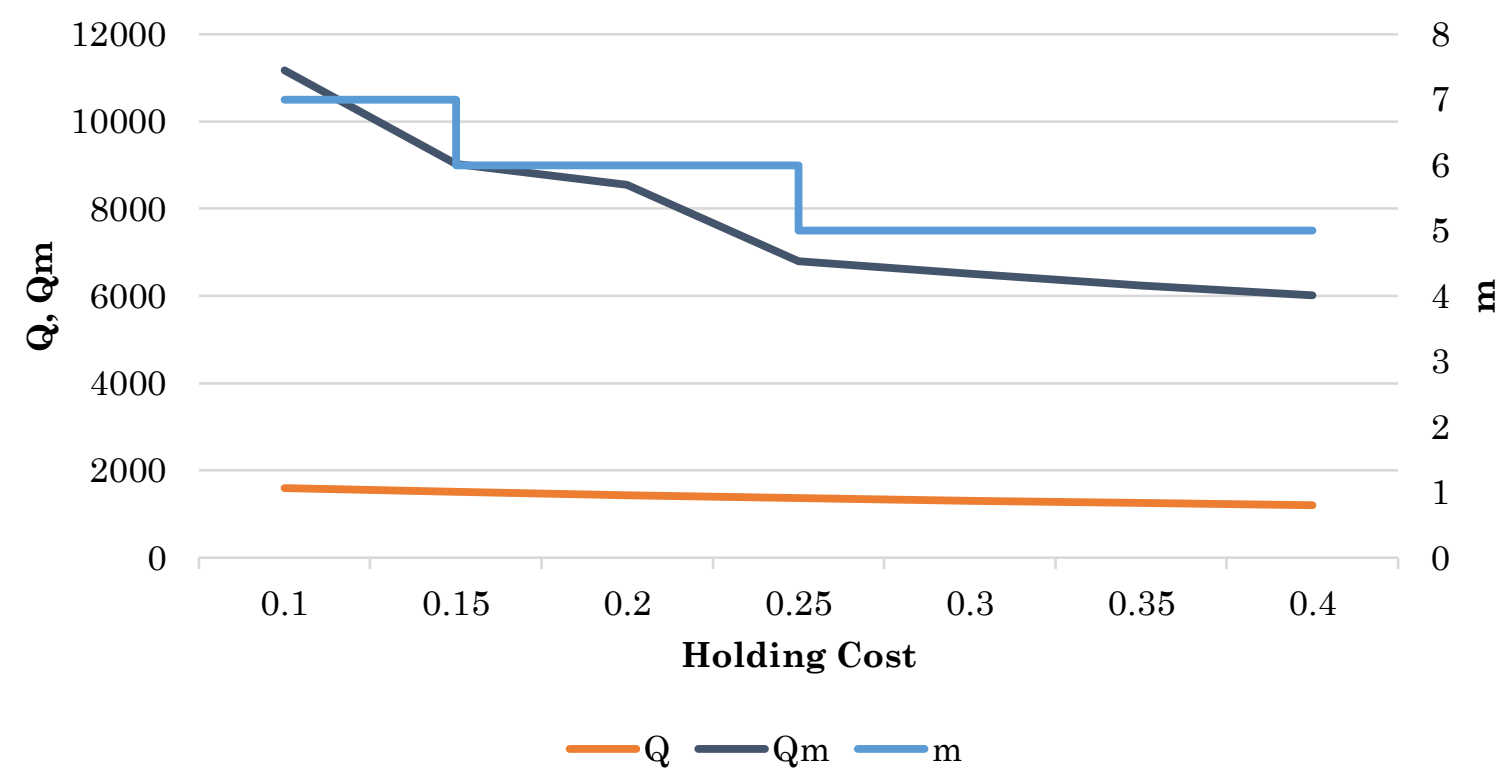

Fig. 4. The changes in the value of vendor holding cost to $\mathrm{Q}$ and $\mathrm{m}$

Fig. 4 indicated an increment in the vendor's holding cost would decrease $\mathrm{Q}, \mathrm{m}$, and Qm's value. There was a step trend decrement in the value of $m$ due to its integer and constant value in the range of particular holding costs. If $\mathrm{m}$ is constant at a certain cost range, Q's value will decrease to minimize the joint total expected cost. 
This result was vice versa to the increment in the vendor's setup cost. It means that the higher the vendor's holding cost or lower the vendor's set up cost, the vendor tends to lower its production lot size $(\mathrm{Qm})$ to minimize the joint total expected cost and vice versa. This finding is consistent with the previous research [6].

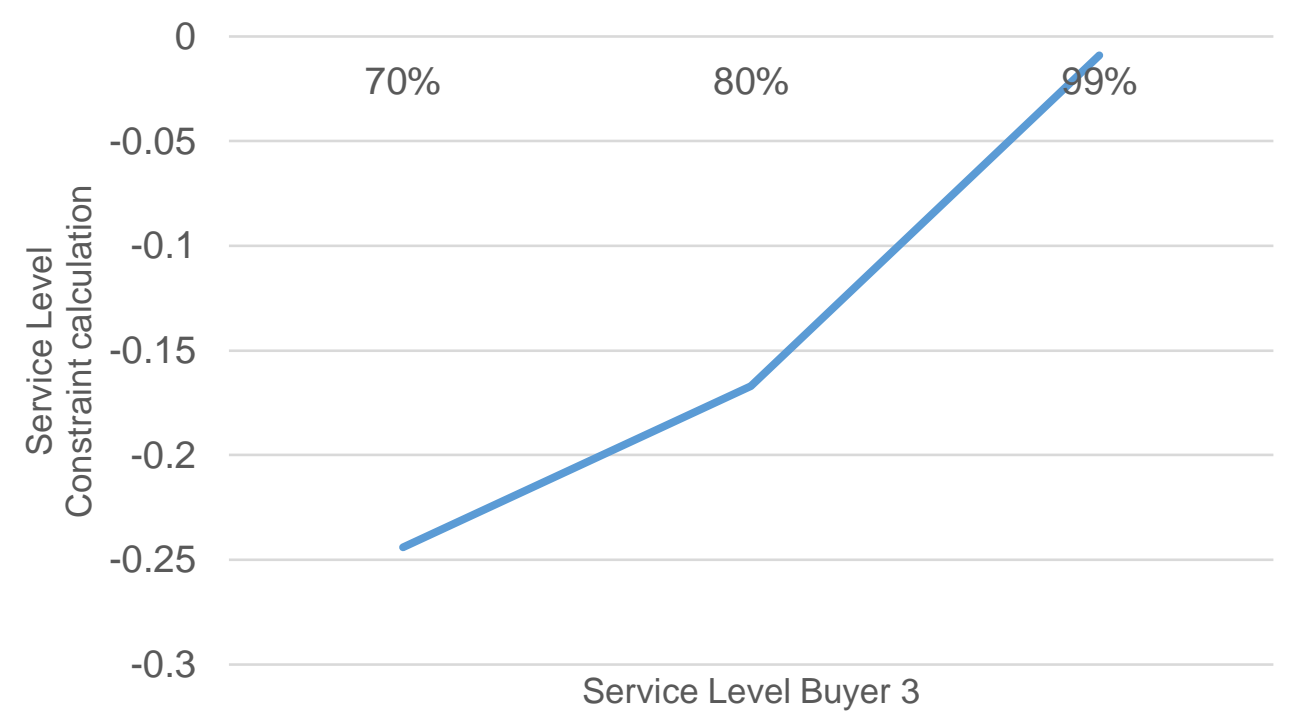

Fig. 5. Effect of service level to the value of $\mathrm{Q}$ and $\mathrm{m}$

Fig. 5 projected that an increment in the value of service level could increase the calculation result of service level constraint on the $\mathrm{Q}$ and $\mathrm{m}$ remain constant. A positive value in the calculation meant that the service level constraint was not satisfied and vice versa. To satisfy the increased service level, the value of $Q$ should be increased, which would decrease the value of $\mathrm{m}$. The result was vice versa to the increment of buyer warehouse capacity or buyer capital capacity. The higher capacity indicated that the buyer could fulfill the optimal value of $\mathrm{Q}$ and $\mathrm{m}$.

The buyer's capacity was divided into loose, tight, and medium categories. The buyer who was in the loose category had high flexibility against the change because of its capacity. Thus, with the same value of $\mathrm{Q}$ and $\mathrm{m}$, the buyer still would be able to comply with it even though there was a change in other parameters' value. The buyer who was in the medium category had low flexibility. An increment in the value of $Q$ and $m$ would make the buyer in this category unable to fulfill it. Meanwhile, the buyer who was in the tight category cannot fulfill the value of $\mathrm{Q}$ and $\mathrm{m}$, so some adjustments were needed. The adjustments were to lower service level, increase the capacity, or decrease Q's value.

\section{Conclusion}

The developed model can overcome previous research weaknesses by considering capital and warehouse capacity constraints. Parameter value (holding cost, set up cost, buyer service levels, buyer capacity) can affect the decision variables value ( $\mathrm{Q}$ and $\mathrm{m}$ ) to minimize the joint total expected cost. In case of increment in holding cost, the vendor tends to reduce the lot size to minimize the joint total expected cost. It is vice versa to the increment in set up cost. An increment in buyer service level can increase lot size 
and reduce order frequency. The buyer capacity is essential to determine its capability to apply the optimal replenishment policy.

For further research, crashing lead time can be considered more because it relates to responsiveness and customer satisfaction. The model can be modified by removing or adding indexes as required to solve other cases.

\section{References}

[1] I. Mas'udin and M. S. Kamara, "Electronic Data Interchange and Demand Forecasting Implications on Supply Chain Management Collaboration: A Customer Service Perspective," Jurnal Teknik Industri, vol. 18, pp. 138-148, 2017. https://doi.org/10.22219/JTIUMM.Vol18.No2.138-148.

[2] M. Mofokeng Teboho and R. Chinomona, "Supply chain partnership, supply chain collaboration and supply chain integration as the antecedents of supply chain performance," South African Journal of Business Management, vol. 50, pp. 1-10, 2019. https://doi.org/10.4102/sajbm.v50i1.193.

[3] L. Yang, H. Li, and J. F. Campbell, "Improving Order Fulfillment Performance through Integrated Inventory Management in a Multi-Item Finished Goods System," Journal of Business Logistics, vol. 41, pp. 54-66, 2020. https://doi.org/10.1111/jbl.12227.

[4] G. Hadley and T. M. Whitin, Analysis of inventory systems. Biblioteca Central: Englewood Cliffs, N. J. : Prentice-Hall, 1963.

[5] R. J. Tersine, Principles of inventory and materials management. New Jersey: Prentice Hall, 1994.

[6] J. K. Jha and K. Shanker, "Single-vendor multi-buyer integrated productioninventory model with controllable lead time and service level constraints," Applied Mathematical Modelling, vol. 37, pp. 1753-1767, 2013. https://doi.org/10.1016/j.apm.2012.04.042.

[7] S. K. Goyal, "An integrated inventory model for a single supplier-single customer problem," International Journal of Production Research, vol. 15, pp. 107-111, 1977. https://doi.org/10.1080/00207547708943107.

[8] S. Lee, Y. J. Kim, T. Cheong, and S. H. Yoo, "Effects of Yield and Lead-Time Uncertainty on Retailer-Managed and Vendor-Managed Inventory Management," $\begin{array}{lllll}\text { IEEE Access, vol. } & \text { 7, pp } & \text { 176051-176064, } & \end{array}$ https://doi.org/10.1109/ACCESS.2019.2957595.

[9] K. Aritonang, M. Nainggolan, and A. V. Djunaidi, "Integrated Supply Chain for a Single Vendor and Multiple Buyers and Products with Crashing Lead Time," International Journal of Technology, vol. 11, pp. 642-651, 2020. https://doi.org/10.14716/ijtech.v11i3.3750.

[10] S.-P. Huang, "Using simple and efficient algorithm involving ordering cost reduction and backorder price discount on inventory system under variable lead time," Information Technology Journal, vol. 9, pp. 804-810, 2010. https://doi.org/10.3923/itj.2010.804.810.

[11] S.-L. Hsu and C. C. Lee, "Replenishment and lead time decisions in manufacturer-retailer chains," Transportation Research Part E: Logistics and Transportation Review, vol. 45, pp. 398-408, 2009. https://doi.org/10.1016/j.tre.2008.10.005.

[12] N. A. Kurdhi, A. Jamaluddin, W. A. Jauhari, and D. R. S. Saputro, "A periodic review integrated inventory model with controllable safety stock and setup cost under service level constraint and distribution-free demand," in Journal of 
Physics: Conference Series, 2017, p. 012022. https://doi.org/10.1088/17426596/855/1/012022.

[13] Q. Mou, Y. Cheng, and H. Liao, "A note on "lead time reduction strategies in a single-vendor-single-buyer integrated inventory model with lot size-dependent lead times and stochastic demand"," International Journal of Production Economics, vol. 193, pp. 827-831, 2017. https://doi.org/10.1016/j.ijpe.2017.09.012.

[14] M. Vijayashree and R. Uthayakumar, "A single-vendor and a single-buyer integrated inventory model with ordering cost reduction dependent on lead time," Journal of Industrial Engineering International, vol. 13, pp. 393-416, 2017. https://doi.org/10.1007/s40092-017-0193-y.

[15] M. AlDurgam, K. Adegbola, and C. H. Glock, "A single-vendor singlemanufacturer integrated inventory model with stochastic demand and variable production rate," International Journal of Production Economics, vol. 191, pp. 335-350, 2017. https://doi.org/10.1016/j.ijpe.2017.05.017.

[16] M. A. Hoque and A. Bhattacharya, "A manufacturer-buyers integrated inventory model with generic distribution of lead times to deliver equal and/or unequal batch sizes," Computers \& Operations Research, vol. 124, p. 105047, 2020. https://doi.org/10.1016/j.cor.2020.105047.

[17] J.-J. Liao, K.-J. Chung, and K.-N. Huang, "A deterministic inventory model for deteriorating items with two warehouses and trade credit in a supply chain system," International Journal of Production Economics, vol. 146, pp. 557-565, 2013. https://doi.org/10.1016/j.ijpe.2013.08.001.

[18] L.-Y. Ouyang, C.-H. Ho, C.-H. Su, and C.-T. Yang, "An integrated inventory model with capacity constraint and order-size dependent trade credit," Computers \& Industrial Engineering, vol. 84, pp. 133-143, 2015. https://doi.org/10.1016/j.cie.2014.12.035.

[19] H. Tarhini, M. Karam, and M. Y. Jaber, "An integrated single-vendor multi-buyer production inventory model with transshipments between buyers," International Journal of Production Economics, vol. 225, p. 107568, 2020. https://doi.org/10.1016/j.ijpe.2019.107568.

[20] D. M. Utama, "Model Penentuan Lot Pemesanan Dengan Mempertimbangkan Unit Diskon dan Batasan Kapasitas Gudang dengan Program Dinamis," Jurnal $\begin{array}{llllll}\text { Teknik Industri, } & \text { vol. } & \text { 18, } & \text { pp. } & \text { 94-102, } & \end{array}$ https://doi.org/10.22219/JTIUMM.Vol18.No1.94-102.

[21] I. Bendavid, Y. T. Herer, and E. Yücesan, "Inventory management under working capital constraints," Journal of Simulation, vol. 11, pp. 62-74, 2017. https://doi.org/10.1057/s41273-016-0030-0.

[22] S. K. D. B. Maulana, D. M. Utama, M. S. Asrofi, I. S. Ningrum, N. Alba, H. A. Ahfa, et al., "The Capacitated Sustainable EOQ Models: Models Considering Tax Emissions," Jurnal Teknik Industri, vol. 21, pp. 12-21, 2019. https://doi.org/10.22219/JTIUMM.Vol21.No1.12-21.

[23] B. Sarkar, W. Ahmed, S.-B. Choi, and M. Tayyab, "Sustainable Inventory Management for Environmental Impact through Partial Backordering and Multi$\begin{array}{llll}\text { Trade-Credit-Period," } \quad \text { Sustainability, } & \text { vol. } & 10,2018 .\end{array}$ https://doi.org/10.3390/su10124761.

[24] S. Tiwari, W. Ahmed, and B. Sarkar, "Multi-item sustainable green production system under trade-credit and partial backordering," Journal of Cleaner Production, vol. 204, pp. 82-95, 2018. https://doi.org/10.1016/j.jclepro.2018.08.181.

[25] A. K. Agrawal and S. Yadav, "Price and profit structuring for single manufacturer multi-buyer integrated inventory supply chain under price-sensitive demand 
condition," Computers \& Industrial Engineering, vol. 139, p. 106208, 2020. https://doi.org/10.1016/j.cie.2019.106208.

[26] Y.-C. Tsao, Q. Zhang, H.-P. Fang, and P.-L. Lee, "Two-tiered pricing and ordering for non-instantaneous deteriorating items under trade credit," Operational Research, vol. 19, pp. 833-852, 2019. https://doi.org/10.1007/s12351-017-0306-9.

[27] A. Banu and S. K. Mondal, "Analyzing an inventory model with two-level trade credit period including the effect of customers' credit on the demand function using q-fuzzy number," Operational Research, vol. 20, pp. 1559-1587, 2020. https://doi.org/10.1007/s12351-018-0391-4.

[28] B. C. Giri and S. Sharma, "Optimal ordering policy for an inventory system with linearly increasing demand and allowable shortages under two levels trade credit financing," Operational Research, vol. 16, pp. 25-50, 2016. https://doi.org/10.1007/s12351-015-0184-y.

[29] W. L. Winston and J. B. Goldberg, Operations research: applications and algorithms vol. 3: Thomson/Brooks/Cole Belmont eCalif Calif, 2004.

[30] M. A. Hoque, "Synchronization in the single-manufacturer multi-buyer integrated inventory supply chain," European Journal of Operational Research, vol. 188, pp. 811-825, 2008. https://doi.org/10.1016/j.ejor.2007.05.019. 